\title{
Floristic structure and composition of Guadua forests in the Colombian coffee region ${ }^{1}$
}

\author{
Fernando Ramírez-Díaz², Juan Carlos Camargo-García ${ }^{2}$
}

\section{ABSTRACT}

In the coffee region (900-2,000 $\mathrm{m}$ a.s.1.) of the Colombian Andes, the forest remnants correspond mainly to fragments dominated by the bamboo species Guadua angustifolia Kunth (Guadua). These highly fragmented forests are found in landscapes with a high degree of transformation due to the agricultural activity and urban expansion. With the purpose of contributing to the knowledge of the ecological characteristics of these forests, the floristic structure and composition (alpha, beta and gamma diversity) of seven forest fragments located in the middle (Quindío) and lower basins of the La Vieja river (Risaralda) were studied. A total of 70,961 individuals and 172 species belonging to 54 families were found. Fifty percent of the families were represented by only one species, and the families Araceae and Leguminosae showed the highest taxonomic richness, respectively with 21 and 14 species. The diversity indices for these forests revealed values comparable to those of tropical forest ecosystems (Shannon-Weiner values between 3,167 and 3,798). Likewise, the cluster analysis (based on Euclidean distances) showed that the stands present a similarity below 0.65 (65\%), associated with the 35 species reported, in seven fragments that characterize a varied floristic composition. This finding implies that these fragments should not be seen as isolated units, but as sites embedded in a diverse regional landscape. This represents important habitats for these species, which are capable of maintaining significant levels of diversity, even under management conditions.

KEYWORDS: Guadua angustifolia, Araceae, Leguminosae, bamboo.

\section{INTRODUCTION}

Biodiversity protection, which includes conservation, information generation and ecological risk evaluation, is one of the six global environmental challenges (McBratney et al. 2014). In Colombia, with approximately 25,163 plant species, it is

\section{RESUMO}

Estrutura e composição florística de bosques de Guadua na região cafeeira da Colômbia

$\mathrm{Na}$ região cafeeira (900-2.000 $\mathrm{m}$ de altitude) dos Andes colombianos, os remanescentes florestais correspondem, principalmente, a fragmentos dominados pela espécie de bambu Guadua angustifolia Kunth (Guadua). Essas florestas altamente fragmentadas são encontradas em paisagens com alto grau de transformação devido à atividade agrícola e à expansão urbana. Com o objetivo de contribuir para o conhecimento das características ecológicas dessas florestas, a estrutura e composição florística (diversidade alfa, beta e gama) de sete fragmentos florestais localizados nas bacias mediana (Quindío) e inferior do rio La Vieja (Risaralda) foram estudadas. Foram observados 70.961 indivíduos e 172 espécies pertencentes a 54 famílias. Cinquenta por cento das famílias foram representadas por uma só espécie, e as famílias Araceae e Leguminosae mostraram a maior riqueza taxonômica, com 21 e 14 espécies, respectivamente. Os índices de diversidade para essas florestas revelaram valores comparáveis a ecossistemas de florestas tropicais (valores de Shannon-Weiner entre 3.167 e 3.798). De modo semelhante, a análise de agrupamento (baseada em distâncias euclidianas) mostrou que os povoamentos apresentam similaridade abaixo de 0,65 (65\%), associada às 35 espécies reportadas, em sete fragmentos que caracterizam uma composição florística variada. Essa descoberta indica que estes fragmentos não devem ser vistos como unidades isoladas, mas como locais inseridos em uma paisagem regional diversificada. Isso representa habitats importantes para essas espécies, os quais são capazes de manter níveis significativos de diversidade, mesmo sob condições de manejo.

PALAVRAS-CHAVE: Guadua angustifolia, Araceae, Leguminosae, bambu.

important to consider the knowledge gap that still exists regarding these plants (Moreno et al. 2017).

The transformation of natural ecosystems for land use defines landscapes with diverse natural and anthropogenic spaces, in terms of their shape, size and disposition (Forman \& Godron 1986, Krummel et al. 1987). The spatiotemporal patterns 
of these mosaics are the result of complex physical, biological, social and economic interactions (Urban et al. 1987) and suggest a relationship between the spatial configuration of these areas and their ecological processes (O’Neill et al. 1988).

For more than three decades, research has noted that forest fragmentation leads to habitat loss and is therefore a threat to biodiversity (Wilcox \& Murphy 1985, Noss 1987), because isolation generates a lack of continuity in spaces resulting from fragmentation (Noss \& Cooperride 1994).

This phenomenon has continued and, between 1990 and 2015, over 129 million ha of forest have been lost worldwide, representing a $3.1 \%$ decrease in the planet vegetation coverage (FAO 2016). In the tropics, this process has been more intense, with a change that represents a loss of $9.94 \%$ in the same period (Payn et al. 2015).

Fragmentation implies a reduced amount of habitat, with more distant and smaller fragments and, therefore, a decreased biodiversity, even threatening the survival of the affected species (Saunders et al. 1991, Andrén 1994, Fahrig 2003).

The Colombian Andean region, where a large number of forest patches result from deforestation and land-use change, is no stranger to fragmentation processes. Although in a conservative scenario González et al. (2011) projected a deforestation rate of 240,000 ha for the 2010-2015 period, 161,721 deforested ha were actually reported (IDEAM 2018), which, although lower, is worrisome, because this figure represents an annual loss of approximately 36,745 ha (IDEAM 2018) or $17 \%$ of the national total (IDEAM 2018a).

In the Colombian coffee region (between $900 \mathrm{~m}$ and 2,000 $\mathrm{m}$ a.s.1.), there are approximately 28,000 ha of forests dominated by the bamboo species Guadua angustifolia Kunth (Guadua) (Kleinn \& Morales 2006), which represent the regional forest resources. Through the culm harvest, these forests have been an important source of wood used for various purposes and have been a production alternative for farming communities linked to this region (Camargo et al. 2007a). This harvest also represents a growing threat to the biodiversity present in this unique ecosystem, a habitat with an immense biological diversity and a major player in the Colombian coffee region landscape. These forests have also been strongly affected by agricultural and urban expansion and have experienced an approximate reduction of $70 \%$ in the last 25 years (Muñoz 2017).

With the purpose of enhancing the value of these forests and generating useful information on their ecological conditions and importance for the Andean plant diversity, this study was conducted regarding the floristic structure and composition of these forests.

\section{MATERIAL AND METHODS}

Considering the high degree of fragmentation of these forests, which generates structural conditions at the landscape level that are unique to these ecosystems, with elongated shapes and sizes that usually do not surpass 5 ha (Camargo \& Cardona 2005), a sampling design was established in completely random parcels, which allows an adequate approximation of these forests at the inventory level (Camargo et al. 2007b).

Two rural areas were selected for sampling in the lower-middle basin of the La Vieja river, which represents the previously described landscape: southwest of the municipality of Pereira (zone 1), Yarima and San Miguel farms; southwest of the municipality of Montenegro (zone 2), La Esmeralda Guadua forest core (Núcleo Forestal de Guadua La Esmeralda - NFGLE) and Nápoles farm. Then, a total of 89 square plots measuring $10 \mathrm{~m}$ x $10 \mathrm{~m}\left(100 \mathrm{~m}^{2}\right)$ were randomly established in seven bamboo forest fragments (four in zone 1 and three in zone 2), called stands here, totaling 135.02 ha (Table 1).

Sampling was performed according to the Gentry (1982) methodology, with the adaptations proposed by Villarreal et al. (2006). Four sampling events were conducted between December 2012 and October 2013 to complete the hydrological

Table 1. Relation of the seven stands studied (location, area and number of parcels).

\begin{tabular}{llcc}
\hline \multicolumn{1}{c}{ Stand } & \multicolumn{1}{c}{ Location } & Area (ha) & $\mathrm{N}^{\mathrm{o}}$ of parcels \\
\hline Stand 1 & Yarima farm & 10.43 & 19 \\
Stand 2 & Yarima farm & 6.93 & 17 \\
Stand 3 & Yarima farm & 10.96 & 10 \\
Stand 4 & NFGLE $^{1}$ & 3.60 & 13 \\
Stand 5 & NFGLE & 7.70 & 20 \\
San Miguel & Risaralda & 7.00 & 5 \\
Nápoles & Quindío & 88.40 & 5 \\
\hline Total & \multicolumn{1}{c}{-} & 135.02 & 89 \\
\hline
\end{tabular}

${ }^{1}$ NFGLE: Núcleo Forestal de Guadua La Esmeralda. 
cycle and identify the flora dynamics of the forest patches.

The plant material found in the plots was photographed with a Canon ${ }^{\circledR}$ EOS Rebel T3i camera, including both the vegetative and sexual parts, for later determination using the taxonomic keys by Gentry (1996), Vargas (2002), Agudelo et al. (2006) and Montañez \& Gómez (2008), and was subsequently grouped using the APG III classification system (Chase 2009). For the correct nomenclature of the species and families, a list of plant names from the Kew Royal Botanic Gardens and the Missouri Botanical Garden was used (The Plant List 2013).

After the taxonomic classification, the absolute abundance, relative abundance, absolute frequency and relative frequency were determined at the species and family levels. From the number of species and families, the taxonomic richness (number of species and families) was obtained, both at the combined level of the seven fragments and within each of them.

The different alpha diversity indices, Margalef richness, Shannon diversity, Simpson's dominance and Pielou equitability indices were calculated using the Past software (Hammer 2001). The beta diversity indices, Euclidean similarity and Bray Curtis distance were calculated with the EstimateS v. 9 software (Colwell 2013). The dendrograms of distance and similarity were determined using the Past software.

\section{RESULTS AND DISCUSSION}

A total of 70,961 individuals, with 172 species belonging to 54 families, were found in the 89 plots, which were distributed in the seven stands located in the two evaluated zones. Fifty percent of the families were represented by only one species, while the families Araceae, Leguminosae and Lauraceae had the highest taxonomic richness, respectively with 21 , 14 and 8 species.

The most abundant families were Araceae (26.08\%), Piperaceae (12.47\%), Urticaceae (8.42\%) and Rubiaceae $(8.18 \%$ ), while Cannabaceae and Sapotaceae had a lower abundance $(0.001 \%$ each).

Of the 172 species, nine $(5.23 \%)$ reported a frequency of a single individual, while $35(20.35 \%)$ were frequent in a single stand. The seven species with the highest relative abundance were Dieffenbachia tonduzii Croat \& Grayum 1999 (10.8 \%), Urera baccifera (L.) Gaudich. ex Wedd. 1852 (6.9 \%), Psychotria hazenii Standl. 1930 (6.7 \%), Piper aduncum L. 1753 (5.9 \%), Anthurium myosuroides (Kunth) Endl. 1837 (5.1\%), Piper augustum Rudge 1805 (4.3\%) and Stromanthe jacquinii (Roem. \& Schult.) H.A.Kenn. \& Nicolson 1975 (3.6\%).

Stands 1 and 2, located on the Yarima farm, had the largest numbers of families (45 and 44, respectively), while the Nápoles and NFGLE stands 4 and 5 had the lowest numbers of families (36, 36 and 34 , respectively). Of the 172 species recorded in the study, $35(20.35 \%)$ were present in the seven stands. The highest relative abundance occurred in the stand 5 of the NFGLE (21.06\%) and stand 2 of the Yarima farm $(20.55 \%)$. The greatest species richness occurred in the stands 1 and 2 of the Yarima farm, with 119 and 106 species, respectively (Figure 1).

The alpha diversity indices showed similar values for each of the seven stands analyzed and showed consistency with the number of individuals and species that represent them in each of the stands (Table 2).

The stands with the highest diversity indices present the highest number of species in the smallest number of individuals, by applying the Shannon diversity index. This result is expressed in the Yarima stand 3 and San Miguel. The lowest diversity indices, on the other hand, are those with the fewest number of species in the highest number of individuals, as evidenced by the NFGLE stand 4 and Nápoles.

With fewer species and fewer individuals, the dominance index is higher, by applying the Simpson's index. This characteristic is evident in the Yarima stand 3 and San Miguel. This dominance, when

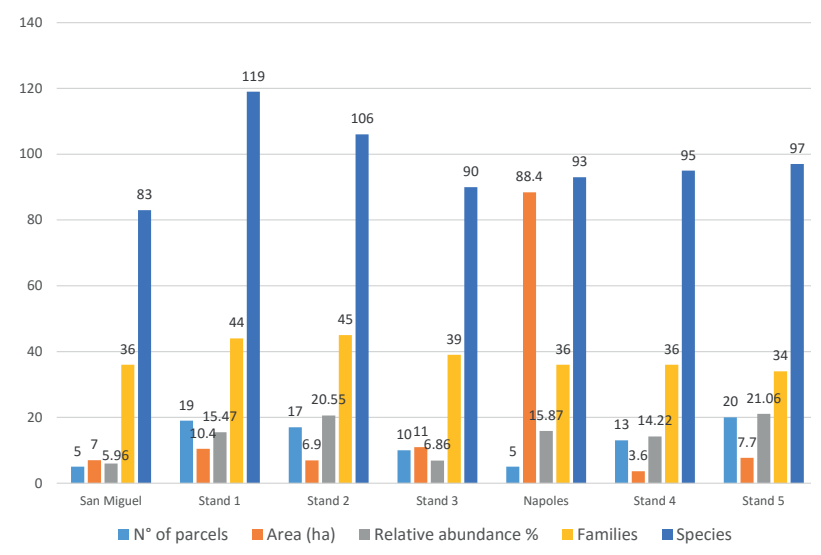

Figure 1. Vegetal species distribution in seven stands of Guadua forests in the Colombian coffee region. Stands 1,2 and 3: Yarima farm; Nápoles and stands 4 and 5: Núcleo Forestal de Guadua La Esmeralda. 
Table 2. Diversity indices for the seven stands of Guadua forests in the Colombian coffee region.

\begin{tabular}{|c|c|c|c|c|c|c|c|}
\hline \multirow[b]{2}{*}{ Nucleus } & \multirow[b]{2}{*}{ Stand } & \multirow[b]{2}{*}{$\begin{array}{l}\mathrm{N}^{0} \text { of species } \\
\text { (S) }\end{array}$} & \multirow[b]{2}{*}{$\begin{array}{l}\mathrm{N}^{\mathrm{o}} \text { of individuals } \\
(\mathrm{N})\end{array}$} & \multicolumn{4}{|c|}{ Alpha diversity } \\
\hline & & & & $\begin{array}{c}\text { Margalef } \\
\text { richness } \\
(\mathrm{R})\end{array}$ & $\begin{array}{c}\text { Shannon } \\
\text { diversity } \\
\left(\mathrm{H}^{\prime}\right)\end{array}$ & $\begin{array}{l}\text { Simpson's } \\
\text { dominance } \\
\quad\left(\mathrm{Si}_{\mathrm{D}}\right)\end{array}$ & $\begin{array}{c}\text { Pielou } \\
\text { equitability } \\
\text { (J') }\end{array}$ \\
\hline \multirow{4}{*}{ Yarima farm } & San Miguel & 83 & 4,226 & 9.822 & 3.664 & 0.963 & 0.829 \\
\hline & Stand 1 & 119 & 10,976 & 12.680 & 3.405 & 0.934 & 0.712 \\
\hline & Stand 2 & 106 & 14,585 & 10.950 & 3.527 & 0.950 & 0.756 \\
\hline & Stand 3 & 90 & 4,871 & 10.482 & 3.798 & 0.968 & 0.844 \\
\hline \multirow{3}{*}{$\mathrm{NFGLE}^{1}$} & Nápoles & 93 & 11,264 & 9.861 & 2.641 & 0.830 & 0.583 \\
\hline & Stand 4 & 95 & 10,092 & 10.196 & 3.167 & 0.920 & 0.696 \\
\hline & Stand 5 & 97 & 14,947 & 9.987 & 3.383 & 0.939 & 0.739 \\
\hline \multirow{2}{*}{ Grand Total } & \multirow{2}{*}{-} & \multirow{2}{*}{172} & \multirow{2}{*}{70,961} & 10.568 & 3.369 & 0.929 & 0.737 \\
\hline & & & & \multicolumn{4}{|c|}{ Average diversity } \\
\hline
\end{tabular}

${ }^{1}$ NFGLE: Núcleo Forestal de Guadua La Esmeralda.

related to diversity, expresses the Pielou equitability indices, which present their highest values in the Yarima stand 3 and San Miguel, while their lowest values were in the NFGLE stand 4 and Nápoles.

When analyzing the relationships between the sampling areas within the stands, the identified species and the recorded individuals, one can see the existing correspondence between the values presented by the Shannon, Simpson and Pielou indices with the relationship between individuals/species, where the lower the value is for the three indices, the lower is the number of individuals per species (Table 3).

The dendrogram resulting from applying the Euclidean similarity index allowed to observe that all stands present a similarity below $0.65(65 \%)$. This finding coincides with the presence of $20 \%$ of the species in all stands, but with the same proportion of those that only appear in one stand and $16 \%$ of those that were found in each stand. The formation of two clusters was revealed: the first formed by the NFGLE stands, Nápoles and stand 2 in the Yarima farm, while the second group was made up of the other stands on the Yarima and San Miguel farms. From the first group, the NFGLE stands 4 and 5 stood out for a similarity of $0.64(64 \%)$, while, in the second group, the stands with the greatest similarity were the stand 3 and San Miguel (Figure 2).

These two clearly differentiated blocks correspond to the individuals/species relationship in Table 3, where the lowest recorded values belong to the stand 3, San Miguel and stand 1 of the block with less Euclidean similarity, and the block with greater similarity corresponds to the largest values of the individuals/species relationship.

The biodiversity values found in stands located in the same geographical space and under the same management conditions (for example, the Yarima farm) presented the highest and lowest taxonomic richness, and this finding is an indicator of the enormous heterogeneity and diversity found. The fact that $20 \%$ of the species appear in all the stands and another $20 \%$ in only one shows the plant variability, even within the same fragment. Londoño \& Prieto (1983) noted that a high heterogeneity is influenced

Table 3. Relationship between sample size and taxonomic richness of Guadua forests in the Colombian coffee region.

\begin{tabular}{|c|c|c|c|c|c|c|c|}
\hline Stand $^{1}$ & Points & Species & Individuals & Species $/ 100 \mathrm{~m}^{2}$ & Individuals $/ 100 \mathrm{~m}^{2}$ & Individuals by species & Order \\
\hline San Miguel & 5 & 83 & 4,226 & 17 & 845 & 51 & 1 \\
\hline Stand 1 & 19 & 119 & 10,976 & 6 & 578 & 92 & 3 \\
\hline Stand 2 & 17 & 106 & 14,585 & 6 & 858 & 138 & 6 \\
\hline Stand 3 & 10 & 90 & 4,871 & 9 & 487 & 54 & 2 \\
\hline Nápoles & 5 & 93 & 11,264 & 19 & 2,253 & 121 & 5 \\
\hline Stand 4 & 13 & 95 & 10,092 & 7 & 776 & 106 & 4 \\
\hline Stand 5 & 20 & 97 & 14,947 & 5 & 747 & 154 & 7 \\
\hline Total & 89 & - & 70,961 & - & - & - & - \\
\hline
\end{tabular}




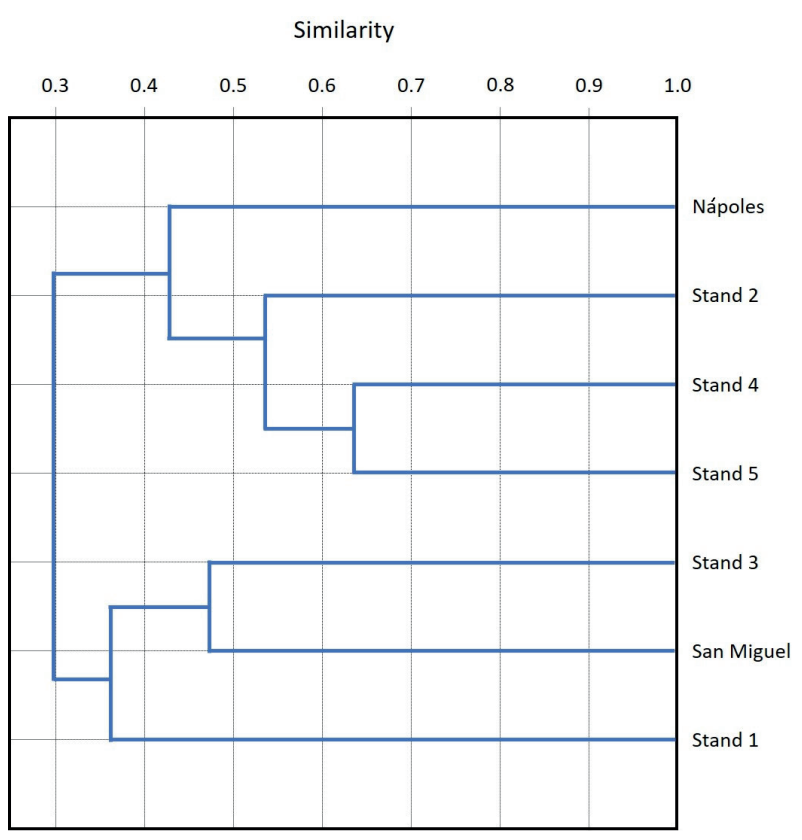

Figure 2. Dendrogram showing the Euclidean similarity indices for seven stands of Guadua forests in the Colombian coffee region.

by anthropogenic factors, such as the edge effect from land use around stands, use and exploitation of forests, and the construction of corridors for ecotourism, among others, which create fragments in heterogeneous spaces.

While forests dominated by G. angustifolia have a relatively low richness and abundance, if compared to forests where G. angustifolia does not dominate, they can host an important group of plant species representative of the Colombian coffee region, thus contributing to the overall biological diversity, what makes it urgent to understand the dynamics of this floristic composition as a function of the biodiversity conservation in the Colombian coffee region landscape.

The variability of the floristic composition of the studied zones is mainly associated with the techniques of bamboo harvesting, because all the floristic diversity associated with the bamboo varieties is conditioned to extractive techniques and to the corridors that growers create within the forest. The high degree of fragmentation and the immersion in a high contrast landscape, where the predominant matrix is pasture, may have implications for biodiversity (Calle \& Méndez 2009).

Many of the species that regenerate within Guadua forests are associated with the first stages of plant succession; however, it is important to analyze species that are within the Guadua forest and that do not have a high regeneration rate in plant succession processes, as is the case for the families Orchidaceae and Bromeliaceae.

The four analyzed forests have diverse areas and are embedded in various agricultural and livestock production matrices. While San Miguel and Yarima are characterized by an agricultural production with a certain level of modernization generating impacts on forest fragments of 7.0 ha and 28.3 ha, respectively, Nápoles has a livestock production around a fragment considerably larger than the studied Guadua forest. Additionally, the NFGLE has developed an agricultural production around coffee and associated crops such as banana, cassava and citrus, at the smallholding scale, with very small fragments. In relation to the fragment areas, these production dynamics directly impact the abundance and richness of the taxa in the study, what is evidenced in stands with a better connectivity, such as Nápoles and Yarima stand 1, which have the greatest areas. Similar results were reported by Ospina (2002), who conducted studies in bamboo forests in some of the areas included in this study.

Diversity indices are descriptors of the structure of taxa, whose increases or decreases allow inferring changes in environmental conditions or in biotic interactions (Ramírez 1999), which distort the simplistic relationships between diversity-stability and diversity-disturbance (Vásquez \& Ramírez 2008 ), what was observed in the variations of indices and abundance of taxa.

The stands that presented the highest richness values were the stands 1 and 2 in Yarima. According to Moreno (2001), index values are dependent on the sample size, and $36 \%$ of the total individuals were counted in these two stands. The lowest richness was in San Miguel, the stand with the lowest number of individuals recorded in the present study.

The highest diversity found in the stand 3 was influenced by the number of species, in relation to the individuals found. This finding indicates that the relative abundance of taxa is only a quantitative factor that is not in itself an indicator of the floristic diversity of the fragments. The number of species was high, in relation to the low number of recorded individuals, what shows that the Shannon index is also a measure of equitability of the populations (Moreno 2001). 
Although dominance tends to have an inverse value to diversity (Moreno 2001), in this study, the same stand that presented the greatest diversity showed the highest dominance, and the trend of the seven stands in the diversity-dominance relationship was the same. This finding can be explained because the difference between the stand dominance and the highest value, with respect to the stand with the lowest value, is 0.04 , a range that does not show significant differences between these stands.

Equitability indices are directly related to diversity (Moreno 2001), what was evidenced by the highest value of equitability of the stand 3 and the lowest value in Nápoles, being consistent with the diversity values recorded.

The similarity index allowed to observe that the stands do not present a similarity greater than $70 \%$, probably due to the different methods of forest use, the soil use of the matrices containing the fragments, the size and shape of the fragments and their relationships with associated water sources, because they share very similar life zones and geological and environmental conditions.

The formation of two groups was observed in the dendrogram. In the first, stands 4 and 5 had the greatest similarity, what can be explained by their lower diversity and taxonomical richness at the species and family level, as well as by their agricultural production, despite being contained in the nine small coffee farms that make up the NFGLE. The similarity of the stand 3 and San Miguel, located in the second group of the dendrogram, is $49 \%$ (0.49), the lowest in the study, what is consistent with the great richness and taxonomic diversity of the study area.

For these considerations to make sense, it becomes necessary to unify and consolidate the methodologies of extractive and forestry exploitation of bamboo that guarantee the sustainability of some of the most important natural ecosystems in the Colombian Andes, which are located in the coffee region.

\section{CONCLUSIONS}

1. The biodiversity values found in the evaluated Guadua forests are highly relevant, not only because they show that these ecosystems can have biodiversity values comparable to those of forest ecosystems with a lower degree of fragmentation and disturbance, but also because these forests have been harvested for decades and could be considered a good example of biodiversity conservation under management conditions, what, in fact, has facilitated the certification under standards such as the Forest Stewardship Council ones;

2. Establishing differences, in terms of diversity (alpha), between the bamboo forests is not completely feasible or clear; however, the distribution and exclusive presence of species in only some of the analyzed fragments shows that they have very interesting particularities, in terms of conserving species, that are not very common in these ecosystems, and this result invites further research on the importance of these exclusive habitats for certain species in highly fragmented landscapes;

3. Faced with the threat of these forests disappearing due to different land-use pressures, the results in this study provide arguments for those responsible for land management that allow elucidating the value of these ecosystems beyond the possibility of obtaining raw material for different commercial uses.

\section{ACKNOWLEDGMENTS}

This study was carried out thanks to the projects “Innovación Tecnológica para la Optimización de Procesos y Estandarización de Productos en Empresas Rurales con Base en la Guadua" (Code 1110452-21121; Contract 442-1-2008) and "El Valor de los Bosques en Paisajes Andinos Fragmentados: El Caso de los Bosques de Guadua en la Región del Eje Cafetero de Colombia" (Contract 117-2015), funded by Colciencias and the Universidad Tecnológica de Pereira. Acknowledgment is also given to the latter for partially financing this project. The owners of the Yarima and La Esmeralda farms played a fundamental role in carrying out this study. Infinite thanks for their hospitality, kindness and trust.

\section{REFERENCES}

AGUDELO, C.; VÉLEZ, M.; SEPÚlVEDA, M.; MACÍAS, D. La flora del Quindío. In: AGUDELO, C. (comp.). Riqueza biótica quindiana. Armenia: Universidad del Quindío, 2006.

ANDRÉN, H. Effects of habitat fragmentation on birds and mammals in landscapes with different proportions of suitable habitat: a review. Oikos, v. 71, n. 3, p. 355-366, 1994. 
CALLE, Z.; MÉNDEZ, L. Estructura y composición de la vegetación arbórea en el agropaisaje del río La Vieja Calle, Z. Méndez, L. In: RODRÍGUEZ, J. M.; CAMARGO, J. C.; NIÑO, J.; PINEDA, A. M.; ARIAS, L. M.; ECHEVERRY, M. A.; MIRANDA, C. L. (ed.). Valoración de la biodiversidad en la ecorregión del eje cafetero. Pereira: Ciebreg, 2009.

CAMARGO, J.; CARDONA, G. Análisis de fragmentación de bosque y guaduales. Pereira: Cipav, 2005.

CAMARGO, J.; GARCÍA, J.; MORALES, T. Bases para la planificación y manejo silvicultural de bosques de Guadua: una aplicación a nivel de finca en la zona cafetera de Colombia. Pereira: Universidad Tecnológica de Pereira/GATA, 2007a.

CAMARGO, J.; GARCÍA, J.; MORALES, T. Mensura e inventario forestal para la planificación y manejo sostenible de bosques de Guadua. Pereira: Universidad Tecnológica de Pereira/GATA, 2007b.

CHASE, M. An update of the Angiosperm Phylogeny Group classification for the orders and families of flowering plants: APG III. Botanical Journal of the Linnean Society, v. 161, n. 1, p. 105-121, 2009.

COLWELL, K. EstimateS: statistical estimation of species richness and shared species from samples: user's guide and application. Version 9. 2013. Available at: http://purl.oclc. org/estimates. Access on: 05 Jan. 2018.

FAHRIG, L. Effects of habitat fragmentation on biodiversity. Annual Review of Ecology, Evolution and Systematics, v. 34, n. 1, p. 487-515, 2003.

FOOD AND AGRICULTURE ORGANIZATION OF THE UNITED NATIONS (FAO). Global forest resources assessment 2015: how are the world's forests changing? 2. ed. Rome: FAO, 2016.

FORMAN, R.; GODRON, M. Landscape ecology. New York: John Wiley and Sons, 1986.

GENTRY, A. A field guide to the families and genera of woody plants of Northwest South America (Colombia, Ecuador, Peru). Chicago: University of Chicago, 1996.

GENTRY, A. Patterns of neotropical plant diversity. Evolutionary Biology, v. 15, n. 1, p. 1-84, 1982.

GONZÁLEZ, J. J.; ETTER, A. A.; SARMIENTO, A. H.; ORREGO, S. A.; RAMÍREZ, C.; CABRERA, E.; VARGAS, D.; GALINDO, G.; GARCÍA, M. C.; ORDOÑEZ, M. F. Análisis de tendencias y patrones espaciales de deforestación en Colombia. Bogotá: Instituto de Hidrología, Meteorología y Estudios Ambientales, 2011.

HAMMER, Ø.; HARPER, D. A. T.; RYAN, P. D. Past: paleontological statistics software package for education and data analysis. Palaeontologia Electronica, v. 4, n. 1, p. 1-9, 2001. Available at: http://palaeo-electronica. org/2001_1/past/issue1_01.htm. Access on: 05 Jan. 2018.

INSTITUTO DE HIDROLOGÍA, METEOROLOGÍA Y ESTUDIOS AMBIENTALES (IDEAM). Reporte de cambio de la superficie cubierta por bosque natural (nacional) por region natural: períodos 2016-2017. 2018. Available at: http://smbyc.ideam.gov.co/MonitoreoBC$\mathrm{WEB} / \mathrm{pub} /$ reporteGeoproceso.jsp?id_reporte $=6923$. Access on: 27 Feb. 2018.

INSTITUTO DE HIDROLOGÍA, METEOROLOGÍA Y ESTUDIOS AMBIENTALES (IDEAM). Décimo quinto boletín de alertas tempranas de deforestación (AT-D): segundo trimestre de 2018. 2018a. Available at: http://smbyc.ideam.gov.co/MonitoreoBC-WEB/pub/ alertasDeforestacion.jsp?0.552487582889916. Access on: 27 Feb. 2018.

KLEINN, C.; MORALES, D. An inventory of Guadua (Guadua angustifolia) bamboo in the coffee region of Colombia. European Journal of Forest Research, v. 125, n. 4, p. 361-368, 2006.

KRUMMEL, J.; GARDNER; R.; SUGIHARA, G.; O'NEILL, R. Landscape patterns in a disturbed environment. Oikos, v. 48, n. 3, p. 321-324, 1987.

LONDOÑO, X.; PRIETO, L. Introducción al estudio fitoecológico de los guaduales del valle geográfico del río Cauca. Tesis (Doctorado en Ingeniería Agronómica) Universidad Nacional de Colombia, Palmira, 1983.

MCBRATNEY, A.; FIELD, D. J.; KOCH, A. The dimensions of soil security. Geoderma, v. 213, n. 1, p. 203-213, 2014.

MONTAÑEZ, N.; GÓMEZ, G. Araceae: el mundo de las espatas multicolores. In: LÓPEZ, A. (comp). Caminos hacia la conservación. Armenia: Centro de Estudios e Investigaciones en Biodiversidad y Biotecnología de la Universidad del Quindío, 2008. p. 57-60.

MORENO, C. Métodos para medir la biodiversidad. Zaragoza: M\&T, 2001.

MORENO, L.A.;ANDRADE, G. I.; RUÍZ-CONTRERAS, L. F. (ed.). Biodiversidad 2016: estado y tendencias de la biodiversidad continental de Colombia. Bogotá: Instituto de Investigación de Recursos Biológicos Alexander von Humboldt, 2017.

MUÑOZ, Procesamiento de imágenes satelitales Landsat $T M, E T M+y$ OLI en la caracterización, clasificación y cuantificación de bosques de "Guadua angustifolia Kunth" entre 1989 y 2016 en el eje cafetero de Colombia: caso de estudio: cuencas bajas de los Ríos Otún y Consota. Tesis (Maestría en Bioinformática y Biología Computacional) Universidad Católica de Manizales, Manizales, 2017. 
NOSS, R. F. Protecting natural areas in fragmented landscapes. Natural Areas Journal, v. 7, n. 1, p. 2-13, 1987.

NOSS, R.; COOPERRIDER, A. Saving nature's legacy: protecting and restoring biodiversity. Washington, D.C.: Defenders of Wildlife, 1994.

O' NEILL, R. V.; KRUMMEL, J. R.; GARDNER, R. H.; SUGIHARA, G.; JACKSON, B.; DEANGELIS, D. L.; MILNE, B. T.; TURNER, M. G.; ZYGMUNT, B.; CHRISTENSEN, S. W.; DALE, V. H.; GRAHAM, R. L. Indices of landscape pattern. Landscape Ecology, v. 1, n. 3, p. 153-162, 1988.

OSPINA, R. Factores que determinan las características florísticas y estructurales de los fragmentos dominados por Guadua angustifolia Kunth en el eje cafetero colombiano y su relación con el aprovechamiento de Guadua. Tesis (Maestría en Ciencias Agrícolas y Recursos Naturales) - Centro Agronómico Tropical de Investigación y Enseñanza, Turrialba, 2002.

PAYN, T.; CARNUS, J.-M.; FREER-SMITH, P.; KIMBERLEY, M.; KOLLERT, W.; LIU, S.; ORAZIO, C.; RODRIGUEZ, L.; SILVAH, L. N.; WINGFIELDI, M. J. Changes in planted forests and future global implications. Forest Ecology and Management, v. 352, n. 1, p. 57-67, 2015.

RAMÍREZ, A. Ecología aplicada: diseño y análisis estadístico. Bogotá: Centro Editorial Escuela Colombiana de Ingeniería, 1999.
SAUNDERS, D. A.; HOBBS, R. J. Y.; MARGULES, C. R. Biological consequences of ecosystem fragmentation: a review. Conservation Biology, v. 5, n. 1, p. 18-32, 1991.

THE PLANT LIST. Version 1.1. 2013. Available at: http:// www.theplantlist.org/. Access on: 27 Feb. 2018.

URBAN, D.; O’NEILL, R. Y.; SHUGART, H. Landscape ecology, a hierarchical perspective. BioScience, v. 37, n. 2 , p. 119-127, 1987.

VARGAS, W. Guía ilustrada de las plantas de las montañas del Quindio y los Andes Centrales. Manizales: Universidad de Caldas, 2002.

VÁSQUEZ, M.; RAMÍREZ, F. Aspectos bioecológicos del orden Trichoptera en su estado larval en la cuenca del río Totare Departamento del Tolima. Ibagué: Universidad del Tolima, 2008.

VILLARREAL, H.; ÁlVAREZ, M.; CÓRDOBA, S.; ESCOBAR, F.; FAGUA, G.; GAST, F.; MENDOZA, H.; OSPINA, M.; UMAÑA, A. Manual de métodos para el desarrollo de inventarios de biodiversidad. Bogotá: Instituto de Investigación de Recursos Biológicos Alexander von Humboldt, 2006.

WILCOX, B.; MURPHY, D. Conservation strategy: the effects of fragmentation on extinction. American Naturalist, v. 125, n. 6, p. 879-887, 1985. 